\title{
Genetic Analysis of Accessions in a Pear Germplasm Bank
}

\author{
P.S. Ritschel, L.F. Revers and \\ P.R.D. de Oliveira \\ Embrapa Uva e Vinho \\ 700-000, Bento Gonçalves, RS \\ Brazil
}

M.E. Ferreira

Embrapa Recursos Genéticos e Biotecnologia

CEP 70770-900, Brasília, DF

Brazil

\author{
G.B. Leite \\ Empresa de Pesquisa Agropecuária e \\ Extensão Rural de Santa Catarina - EPAGRI \\ Estação Experimental de Caçador \\ 89500-000, Caçador, SC \\ Brazil
}

Keywords: Pyrus communis, P. pyrifolia, breeding, molecular characterization, RAPD

\begin{abstract}
Genetic diversity of germplasm collections is the base of breeding programs and it is essential to the raising of new genetic combinations aimed at the development of new cultivars. In Brazil, the pear germplasm collection is maintained in orchards by the EPAGRI-EE Caçador. The aim of this work was to analyze the genetic diversity of an initial sample of 46 accessions of this collection, by Random Amplified Polymorphic DNA (RAPD). European (Pyrus communis), Asian ( $P$. pyrifolia and $P$. ussuriensis) and hybrid cultivars were used. From 160 randomic primers, 11 primers, yielding 87 reproducible and polymorphic markers, were chosen and used for similarity analysis. The cluster analysis resulted in a dendrogram that showed, with few exceptions, European, Asian and hybrid cultivars as distinct groups. By using these markers, the Chinese and Japanese cultivars could be discriminated. The study illustrates how genetic information can be valuable to the organization of germplasm collections. Accessions named differently as 'William's' and 'Bartlett' showed $100 \%$ of genetic similarity and probably correspond to the European pear cultivar 'Bon Chrétien Williams' (synonym: 'Williams - Bartlett de Boston'). On the other hand, two accessions identified with the same name, 'Óstia', did not show genetic identity and are, therefore, distinct accessions. This study is being extended to several other accessions of the collection and completed with the analysis of DNA hypervariable regions (microsatellites).
\end{abstract}

\section{INTRODUCTION}

In Brazil, pear is the fruit that is imported in the greatest quantities and on which most foreign currency is spent (Ibraf, 2006). The lack of cultivars adapted to the edaphoclimatic conditions of Southern Brazil is one of the limiting factors for the development of the crop in the country. As a contribution to overcoming this problem, research activities aimed at the genetic improvement of pear in Brazil were started again from the beginning of 2006 (Oliveira et al., 2006).

The base of genetic breeding is the genetic diversity in the germplasm pool. This variability is essential to develop promising new gene combinations, which is aimed at the development of improved cultivars. Molecular markers are helpful in the genetic analysis of a germplasm bank, by making possible estimates of the allele richness of the collection. Taking this into account, support for the management of Germplasm Banks can be given by the evaluation of the degree of double accessions in the collection, as well as the need for enrichment of the collection with new accessions.

The Pear Germplasm Bank is maintained by EPAGRI - EE Caçador (Empresa de Pesquisa Agropecuária e Extensão Rural de Santa Catarina - Estação Experimental de Caçador), in Santa Catarina state. About 200 accessions are maintained in the field collection. An analysis of the information on the accessions of the collection indicated the 
existence of duplications. There were further doubts as to the identity of some accessions with the same name. On the other hand, the number of entries in the collection is limited, and it will probably be necessary to introduce new accessions to provide adequate parental materials for the Pear Improvement program.

The main purpose of this study was to analyse a 46-accession sample of the pear germplasm collection cultivated by EPAGRI-EE Caçador, with the aim of improving the organization of the pear genetic resources of Brazil, through the identification of duplications and the evaluation of the collection enrichment needs.

\section{MATERIALS AND METHODS}

\section{Plant Material}

The subsample of 46 accessions, selected from among the 200 accessions of the EPAGRI-EE Caçador pear germplasm collection was analyzed. In the selection of the accessions, the sample was intended to be kept as representative as possible, by including cultivars of European (Pyrus communis) and Asian origin ( $P$. pyrifolia and $P$ ussuriensis) as well as hybrid cultivars. The subsample was composed of the following accessions, as identified in the Germplasm Bank: (1) Group of European pear type (P. communis): 'Bartlett', 'Williams', 'Packham's Triumph', 'Winter Bartlett', 'Max Red Bartlett', 'Passe Crassane', 'Coscia Precoce', 'Beurre d'Anjou', 'Curé', 'Beurre Rose', 'Beurre Hardy’, 'Abate Fetel', 'Doyenné du Comice', 'Clapp’s Favorite', 'Rouge Delbard' and 'Carrick'; (2) Hybrid group ( $P$. communis $\times$ P. pyrifolia): 'Le Conte', 'Kieffer', 'Triunfo' and 'Seleta'; (3) Group of Japanese pear type ( $P$. pyrifolia): 'Oku Sankichi', 'Suisei', 'Imamura Aki', 'Shinsui', 'Kousui', 'Hachiko', 'Nijisseiki', 'Kikusui', 'Shinka', 'Gold Nijisseiki', 'Shinseiki', 'Machiro', 'Housui'; (4) Group of Chinese pear type ( $P$. ussuriensis): 'Ya-Li' and 'Tzu-Li'; (5) Group of pears of unknown type and pedigree: 'Pirus1', 'Pirus3', 'Pirus4', 'Pirus5' 'Pirus7', 'Pirus8', 'Pirus9', 'Madame Sieboldt', 'Óstia1', 'Óstia2' and 'Pera d'água'.

\section{RAPD Marker Analysis}

Tissue samples of young pear leaves were cut into strips, ground in liquid nitrogen and the DNA extracted as described by Doyle and Doyle (1990). The extracted DNA was quantified by electrophoresis in minigel (agarose 1\%).

The DNA was PCR-amplified in $13 \mu \mathrm{l}$ containing $1.04 \mu \mathrm{g} \mu \mathrm{l}$ of purified BSA, $0.25 \mathrm{mM}$ of each dNTP, $0.5 \mu \mathrm{M}$ primer, $10 \mathrm{mM}$ Tris-HCl (pH 9.0), $1.5 \mathrm{mM} \mathrm{MgCl}, 1 \mathrm{U}$ of Taq-polymerase and $7.5 \mathrm{ng}$ extracted pear DNA. The amplification conditions were 1 ' at $94^{\circ} \mathrm{C}, 1^{\prime}$ at $35^{\circ} \mathrm{C}$ and $2^{\prime}$ at $72^{\circ} \mathrm{C}$ for 40 cycles and a final extension step at $72^{\circ} \mathrm{C}$ for $5^{\prime}$. The amplification products were separated in horizontal 1.5\% agarose gels stained with ethidium bromide and electrophoresed at constant voltage (100 volts) for 4-5 hours. The gels were visualized by an Eagle Eye II imaging system (Stratagene).

One hundred and sixty random primers (Operon Technologies, USA) were used for the selection of polymorphisms in a subsample of six pear accessions, composed of two accessions of European origin ('Packham's' and 'Williams'), one hybrid ('Kieffer') and three accessions of Asian origin ('Oku Sankishi', 'Housui' and 'Tzu-Li') (Fig. 1A).

\section{Statistical Analysis}

To estimate the information level of the RAPD markers used in the grouping analysis, the marker index was calculated as described by Powell et al. (1996).

The NTSYS software package was used to estimate similarity between accessions, based on RAPD markers as well as for their classification by the clustering algorithm UPGMA (Rohlf, 1992). To estimate similarities between accessions, the DICE coefficient was used. This coefficient is recommended for binary data as adequate for RAPD analyses, since the absence of a specific RAPD marker is not interpreted as 'allele' presence in the test accessions. After the establishment of the similarity matrix, data were grouped by the UPGMA method and the results visualized in a dendrogram. 


\section{RESULTS AND DISCUSSION}

The choice of the most adequate marker for the estimation of the genetic diversity in a species depends on a series of factors such as information content, multiplex capacity, as well as the marker availability for the species of interest, which altogether determine the requirements in labour and costs for the experiments (Rafalski et al., 1996). RAPD markers are obtained by the PCR amplification of DNA segments distributed randomly across the target genome, with the use of random-sequenced oligonucleotide primers (Williams et al., 1990). They are defined as dominant markers once a homozygous is not distinguished from a heterozygous individual in the same locus. The application of exact statistical and reproducible tests in other laboratories is not always possible with RAPD markers. On the other hand, a variable number of polymorphic bands can be observed with the application of a single random primer, which makes the use of RAPD markers with high multiplex capacity in an extensive germplasm analysis recommendable, namely in view of the low cost/benefit ratio.

RAPD markers are being used successfully in genetic analyses, especially in a first approach to the genetic diversity of different plant species (Belaj et al., 2002; Royo and Itoiz, 2004; Piluzza et al., 2005). The diversity and identity of Pyrus species was effectively evaluated by markers (Oliveira et al., 1999; Monte-Corvo et al., 2000; Sawazaki et al., 2002; Teng et al., 2002; Lee et al., 2004).

Confirming these results, the polymorphism generated by the RAPD markers was adequate to estimate the genetic diversity in the pear germplasm collection of EPAGRIEE Caçador. Among the 160 tested primers, 11 markers were chosen based on the consistence of the generated polymorphic fragments (Fig. 1B; Table 1). The total number of polymorphic fragments generated by the markers and used in the grouping analysis was 87, varying between 4 and 10 markers per primer (average of 7.7). The polymorphism indicated by these markers was estimated by the expected heterozygosity, which varied between 0.48 and 0.87. A marker index, which takes the number of polymorphic markers as well as the expected heterozygosity into consideration, was computed to estimate the information level of each RAPD marker; it varied between 2.8 and 8.7 (Table 1 ).

The grouping analysis was visualized in a dendrogram where the European, hybrid and Asian varieties formed distinct groups (Fig. 2). Small discrepancies were observed such as the grouping of genotypes identified as belonging to the occidental type, 'Doyenné du Comice' and 'Carrick', and to the oriental, 'Imamura Aki', which were placed close to the hybrid cultivar group. The identity of these genotypes must be confirmed.

In the European group, the assumption that the accessions, 'William's' and 'Bartlett' (Fig. 2) registered with different names have one and the same identity, which probably corresponded to the European cultivar 'Williams Bon Chrétien' (synonyms: 'Williams - Bartlett of Boston'). On the other hand, two accessions identified with the same name, 'Óstia', did not show genetic similarity, and therefore, represent distinct accessions. The study is being extended to the remaining accessions of the AGB-Pear and completed with the analysis of hypervariable DNA regions (SSR).

The Asian genotypes formed a well-defined group that included all accessions, with the exception of 'Imamura Aki'. Chinese cultivars that belong to the species $P$. ussuriensis could be differentiated from the Japanese types ( $P$. pyrifolia).

The hybrid cultivars, resulting from the cross of $P$. communis and $P$. pyrifolia, were grouped together with other accessions with possible hybrid origins, whose pedigrees were not completely recovered (Pirus1, Pirus3, Pirus4, Pirus5, Pirus7, Pirus8, Pirus9, Madame Sieboldt, Óstia1, Óstia 2 and Pera D’água).

\section{CONCLUSIONS}

The study illustrates that genetic information can be useful for the organization of germplasm collections. 


\section{Literature Cited}

Belaj, A., Satovic, Z., Rallo, L., Trujillo, I. 2002. Genetic diversity and relationships in olive (Olea europaea L.) germplasm collections as determined by randomly amplified polymorphic DNA Theor. Appl. Genet. 105:638-644.

Doyle, J.J. and Doyle, J.L.1990. Isolation of plant DNA from fresh tissue. Focus 12:1315.

Ibraf. Instituto Brasileiro de Frutas. 2006. www.ibraf.org.br.

Lee, G.P., Lee, C.H. and Kim, C.S. 2004. Molecular markers derived from RAPD, SCAR, and the conserved 18S rDNA sequences for classification and identification in Pyrus pyrifolia and P. communis Theor. Appl. Genet. 108:1487-1491.

Monte-Corvo, L., Cabrita, L., Oliveira, C. and Leitão, J. 2000. Assessment of genetic relationships among Pyrus species and cultivars using AFLP and RAPD markers. Genetic Resources and Crop Evolution 47:257-265.

Oliveira, C.M., Mota, M., Monte-Corvo, L., Goulãqo, L. and Silva, D.M. 1999. Molecular typing of Pyrus based on RAPD markers. Scientia Horticulturae 79:163174.

Oliveira, P.R., Ritschel, P., Leite, G.B., Nickel, O. and Degenhardt, J. 2006. Com a genética vamos superar o desafio da produção de pêra? J. da Fruta 123:2.

Powell, W., Morgante, G.B., Andre, C., Hanafey, M., Vogel, J., Tingey, S. and Rafalski, A. 1996. The comparison of RFLP, RAPD, AFLP and SSR (microsatellite) markers for germplasm analysis. Molecular Breeding 2:225-238.

Piluzza, G., Pecetti, L., Bullitta, S. and Piano, E. 2005. Discrimination among subterranean clover (Trifolium subterraneum L. complex) genotypes using RAPD markers. Genetic Resources and Crop Evolution 52:193-199.

Rafalski, J.A., Vogel, J.M., Morgante, M., Powell, W., Andre, C. and Tingey, S.V. 1996. Generating and using DNA markers in plants. p.73-134. In: B. Birren and E. Lai (eds.), Nonmammalian Genomic Analysis: A practical guide, Academic Press Inc., New York.

Rohlf, F.J. 1992. NTSYS-PC: numerical taxonomy and multivariate analysis system version 1.7. Exeter Software, New York.

Royo, J.B. and Itoiz, R. 2004. Evaluation of the discriminance capacity of RAPD, isoenzymes and morphologic markers in apple (Malus $\times$ domestica Borkh.) and the congruence among classifications. Genetic Resources and Crop Evolution 51:153160.

Sawazaki, H.E., Barbosa, W. and Colombo, C.A. 2002. Caracterização e identificação de cultivares e seleções de pereiras através de marcadores RAPD. Rev. Bras. Frutic. 24:447-452.

Teng, Y., Tanabe, K., Tamura, F. and Itai, A. 2002. Genetic relations of Pyrus species and cultivars to East Asia revelead by Random Amplified Polymorphic DNA markers. J. Amer. Soc. Sci. 127:262-270.

Williams, J.G.K., Kubelik, A.R., Livak, K.J., Rafalski, J.A. and Tingey, S.V. 1990. DNA polymorphisms amplifies by arbitrary primers are useful as genetic markers. Nucleic Acid Research 18:6531-6535. 


\section{Tables}

Table 1. Characterization of the RAPD markers used in the diversity analysis of 46 pear germplasm accessions.

\begin{tabular}{lccc}
\hline RAPD marker & Hav $^{1}$ & $\mathrm{E}^{2}$ & $\mathrm{MI}^{3}$ \\
\hline OP-F13 & 0,48 & 6 & 2,9 \\
OP-G4 & 0,87 & 10 & 8,7 \\
OP-H11 & 0,80 & 6 & 4,8 \\
OP-I1 & 0,87 & 6 & 5,2 \\
OP-I14 & 0,72 & 10 & 7,2 \\
OP-I16 & 0,81 & 7 & 5,7 \\
OP-J1 & 0,79 & 8 & 6,3 \\
OP-J13 & 0,80 & 10 & 8,0 \\
OP-K11 & 0,70 & 10 & 7,0 \\
OP-L12 & 0,70 & 4 & 2,8 \\
OP-L2 & 0,76 & 7 & 5,3 \\
\hline
\end{tabular}

${ }^{1} \mathrm{Hav}=$ expected heterozygosity.

${ }^{2} \mathrm{E}=$ multiplex ratio.

${ }^{3} \mathrm{MI}=$ marker index (Powell et al., 1996). 

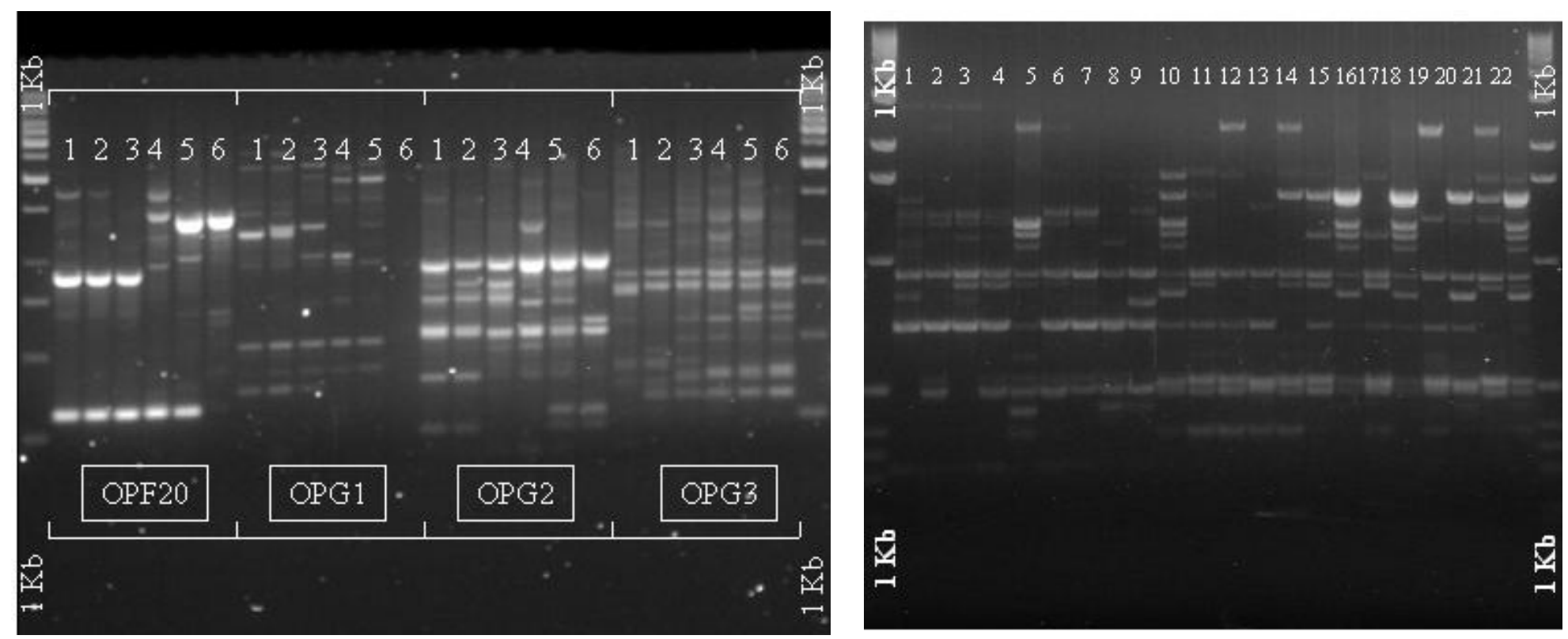

(A)

(B)

Fig. 1. (A) Selection of RAPD markers: 160 random primers (Operon Technologies, USA) were evaluated in a subsample of six pear accessions (Lanes: 1: 'Packham's'; 2: ‘Williams'; 3: ‘Kieffer'; 4: ‘Oku Sankishi’; 5: 'Housui’; 6: ‘Tzu-Li'). Those that generated polymorphic and consistent markers were selected for the analysis of the complete sample. The primer sequences are available upon request. (B) Amplification products of the RAPD primer OP-J13. Based on the consistence of the generated polymorphic markers, 11 random primers were selected for the genetic analysis of AGB-Pear. The genetic profiles of 22 of the 46 pear accessions under study are shown, obtained through marker OP-J13 (Lanes 1: 'Gold Nijisseiki'; 2: 'Machiro' 3: 'Hachiko'; 4: 'Housui'; 5: 'Ya-Li'; 6: 'Tzu-Li'; 7: 'Carrick'; 8: 'Le Conte'; 9: 'Kieffer'; 10: 'Pirus1'; 11: 'Pirus3'; 12: 'Pirus 4'; 13: 'Pirus5'; 14: 'Pirus7'; 15: 'Pirus8'; 16: 'Pirus9’; 17: ‘Triunfo'; 18: 'Madame Sieboldt'; 19: 'Seleta'; 20: ‘Óstia1’; 21: ‘Óstia2’; 22: 'Pera D’água’). 


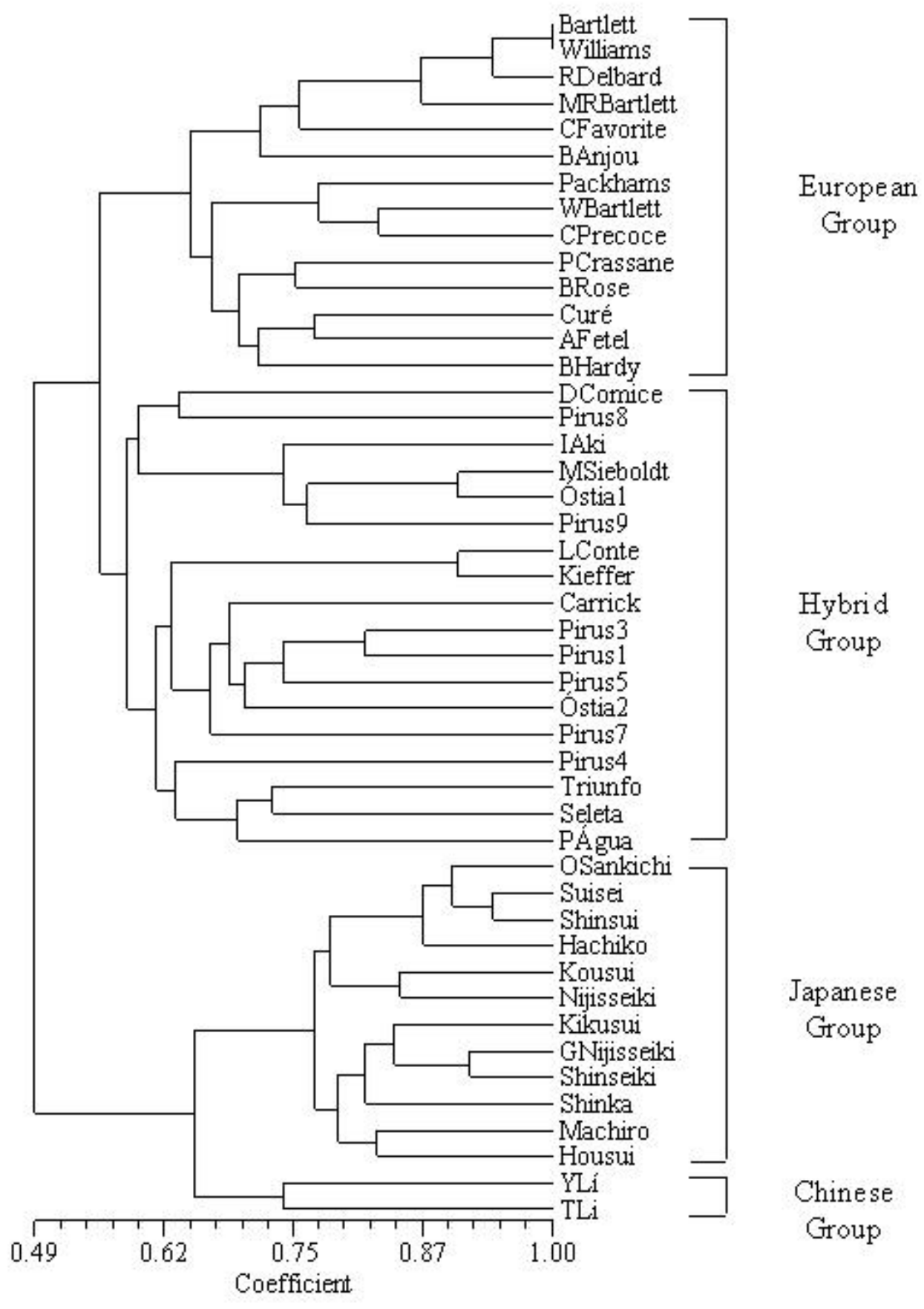

Fig. 2. Dendrogram visualizing the grouping analysis of 46 pear germplasm accessions. The European, hybrid and Asian cultivars formed distinct groups, with few exceptions: the Europeans 'Doyenné du Comice' and 'Carrick', and the oriental 'Imamura Aki' have a position near the hybrid cultivar group. In the group of Asian genotypes, the Chinese were distinguishable from the Japanese cultivars. 
